\title{
The Validity of Problem Based Learning Model To Improve Problem Solving Ability
}

\author{
Sahat Saragih \\ Mathematic Education Departement FMIPA Unimed \\ Jl. Willem Iskandar Psr. V Medan, 20221 \\ Syafari \\ Mathematic Education Departement FMIPA Unimed \\ Jl. Willem Iskandar Psr. V Medan, 20221 \\ Muliyono \\ Mathematic Education Departement FMIPA Unimed \\ Jl. Willem Iskandar Psr. V Medan, 20221
}

\begin{abstract}
The first step of this research purpose to valid the problem based learning model and the instrument problem solving ability on students of Junior High School based on curriculum 2013 in Medan city. The subject of the research was students of grade 7 State Junior High School and Private in Medan city that taken purposively random sampling, that were to select 8 Junior High School randomly with 4 State Junior High School and 4 Private Junior High School for every area in Medan town and suburb. Development Research that oriented on product developing was done by 3 steps. The first step resulted at the beginning model of the problem based learning also the instrument of problem solving ability that was the validation result of Mathematic education practioner, mathematic teacher also have been done limited try out test in the field on learning model and instrument of the research. The result was shown that the valid of learning tools to be used.
\end{abstract}

Keyword: Validity, Problem Based Learning Model, Problem Solving Ability

\section{INTRODUCTION}

The problem solving ability have become focus in mathematic learning in some country. This is suitable with recommendation from NCTM (2000) that said "problem solving must be the focus of school mathematics". According to Ruseffendi (1986) stated that problem solving ability have become central focus in learning mathematic in United of Stated since 1980, this is done by the same by the Singapura country that have done the problem solving ability from Elemantary School and High School (Kaur, 2000). So that the Japan country have been long to change the learning paradigm by applying open ended approach ( the open problem that asked many answer) that done to change the close questions that is only have single answer.

The important of problem solving ability in learning mathematic because in processing of finishing mathematic problem, the students asked to able use the skill and the experience that theirself to apply in finishing the questions that is not routine is one of the special characteristic from mathematic problem. This thing is only done for the students have problem solving ability. Of course the abilty also hoped can be useful for the students to finish the next problems that related to their daily life in society. The wishes suitable with the purpose of learning mathematic that contain in curriculum 2006, 2013, where are in the 
curriculum to place the mathematic problem solving ability as one of the purposes at every competence standard in all every grade of education. To train of problem solving ability need to be of strategy organization. This thing will train the people to critical thinking, logic, creative that is very useful in solving the society development.

Even it is actually when students on the questions problem solving or the questions are not routine, the example of story questions that includes with daily life students to feel difficulty. As the example below:

Pay attention of this figure below.
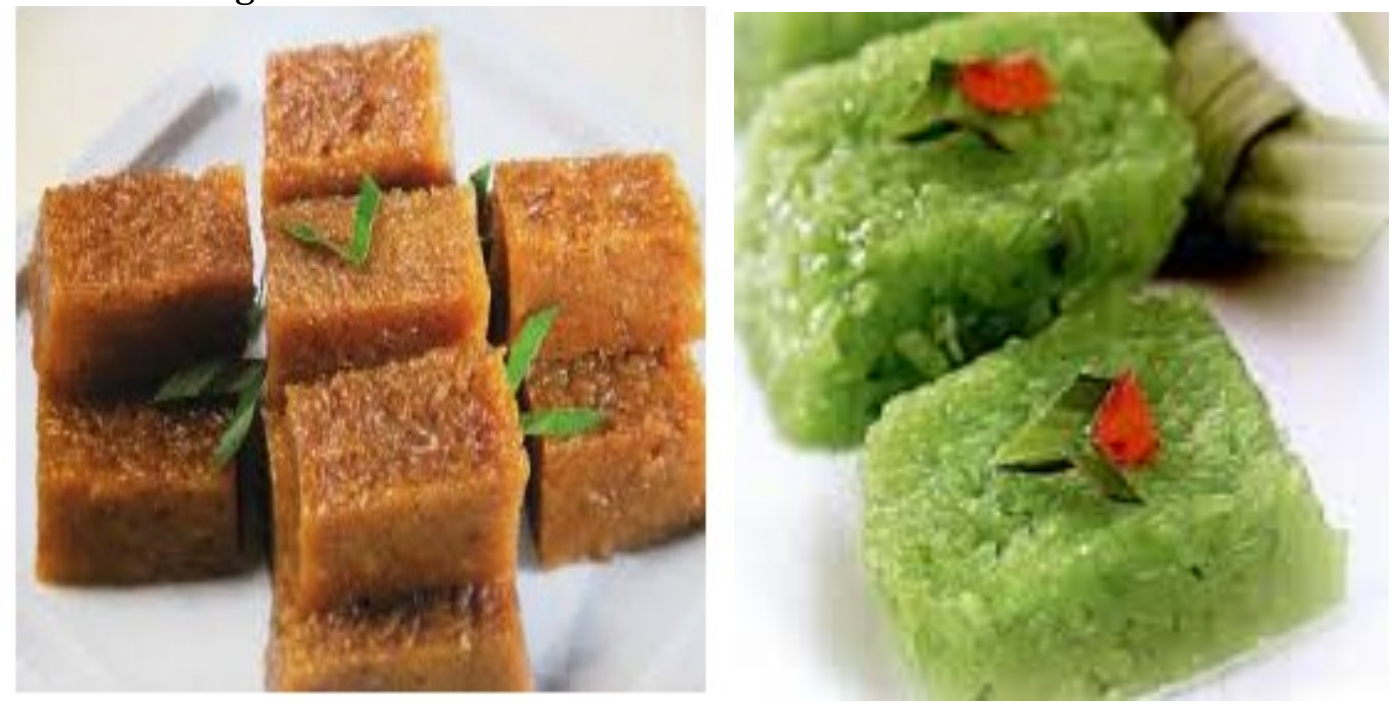

Ms. Purwati makes sweet sticky rice cake with 2 kinds of color, green and brown like picture above. Green cake made as many as 30 pieces, brown cake made as much as 45 pieces. This sweet glutinous cake will be served to a plate with the same amount of lots.

a. Write data from known element and asked on above problem! Is it enough data to determine the number of plates used!

b. Write down how to determine the size of the plate used?

c. Compute the number of plates used by the completion steps in part $b$ ?

d. If Arya argues that the plate used as much as 6 dishes, is it really Aya's answer? Give your reason!

Most students answer the above problem with the answer as in Figure 1.1. Following:

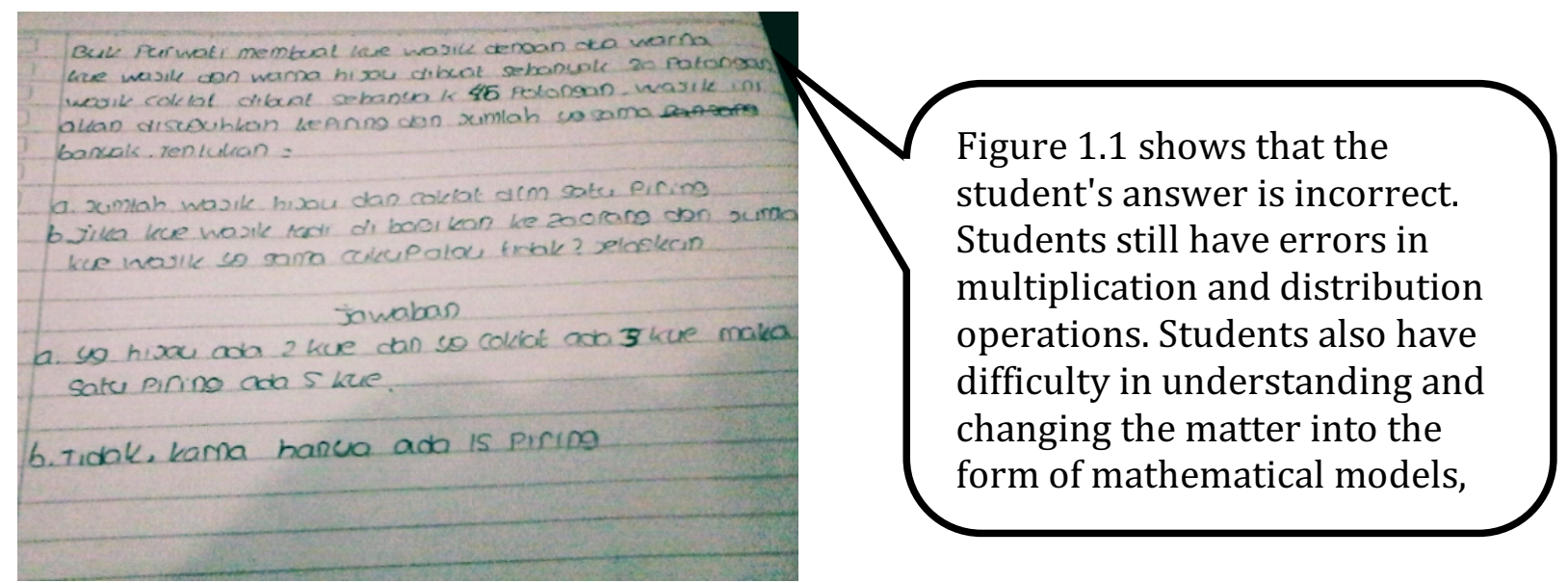

Figure 1.1 Student answers related to Problem Solving 
Based on Figure 1.1, students' answers are incorrect. Students still have errors in multiplication and distribution operations. Students also have difficulty in understanding and changing the matter into the form of mathematical models, then errors in interpreting questions. When analyzed from the student's answer errors from 35 students only 4 people about 11\% who answered correctly without error, 9 (25\%) people answered correctly but there was a misconception, 16 people (45\%) who answered wrongly due to operation error and 6 people 17\%) did not answer. From the analysis of student answers above shows that students' mathematical solving ability is still low. From the student's answer, it is seen that the student has not been able to write down what is known, not yet able to write down what is asked and the adequacy of the data, then the student has not been able to plan the problem solving, as well as solving the student problem and checking again.

The description of the problem solving ability obtained from the research of Saragih and Napitupulu (2015) shows that the ability of high-level mathematical thinking including problem solving ability, reasoning or self-test and self efficacy of junior high school students in North Sumatra is still low. Mandasari (2013), Nupus (2013) in their respective studies reported that creative thinking ability, mathematical problem solving of junior high school students as well as mathematical communication, mathematical problem solving of junior high students. Similarly, the results of research Saragih, Habeahan (2014) showed that the problem solving ability of students of SMP N 2 Siantar is low.

The low level of problem-solving ability is inseparable from the learning process done by teachers in the classroom as well as students' interest and responsiveness to the mathematics itself. Teaching process that takes place during this time in the classroom more often using the algorithm (steps) completion is exemplified by the teacher, so it often happens if the problem is changed a little then the students are confused in solving it. According to Saragih (2013) the learning process that teachers do today is teacher-centered (teacher oriented) is less train the students reasoning power and only emphasizes the memorization of concepts and mathematical procedures to solve the problem. Students have no alternative in working on the problem so that when there is difficulty then the students do not have other hand to be guide. Students will use the procedure "origin so" because of the lack of understanding of the meaning of the algorithm it uses.

The mathematics learning reform of a teacher-oriented approach is teacher-oriented to a student-oriented approach that is learned by imitating learning by understanding that "knowing mathematics is doing mathematics, that is learning which emphasizes doing or process as compared to "knowing that" is a thing to do. In terms of carrying out the math that is presented in an open matter, students are required to examine, explore, communicate, conjecture, mingle justification, and draw up arguments. To encourage creative thinking, and problem-solving skills can be done with problem-based approaches (presenting non-routine issues as well as open issues that demand cognitive and metacognitive strategies), group learning as well as student-centered interactive learning.

Problem-Based Learning Model (PBM) is one of the innovative student-centered learning models that can provide students with active and creative conditions. Characteristics of PBM according to Arends (2008) include learning that prioritizes the filing of problems or questions, focusing on interdisciplinary linkages, authentic investigation, cooperation, and producing works or demonstrations. The PBM model requires that students actively solve the problem at hand, so as to enable students to become self-reliant learners. 
A number of preliminary studies of Saragih \& Habeahan (2014) indicate that the improvement of problem solving skills and mathematical creativity of students taught by problem-based learning is higher than conventional learning, and the process of student responses taught by problem-based learning is more varied and better than conventional learning. The results are not much different by Mandasari (2013) in his research also showed improvement of creative thinking ability and problem solving of mathematical students who are given Problem Based Learning model using autograph software better than students who are given regular learning. The result of Nufus (2013) study shows that the improvement of problem solving ability and mathematical communication through the application of PBM is better than that of students who get regular learning. Hia (2009) suggests that problem-based learning has a positive effect on mathematics learning outcomes. Sinaga (2007) shows that the mathematics learning model based on the culture-based problem of batak produces the percentage of students' learning mastery achievement in the classical, student and teacher responses, the average of the category of teacher ability to manage the learning in the good category. A very interesting problem, how is the problem-based learning model designed and implemented in order to improve problem-solving and proofing capabilities?

\section{Problem Solving Ability}

\section{REVIEW OF THE LITERATURE}

Problem-solving skills are part of a high-level mathematical thinking ability that is an important factor and a goal in mathematics learning and is included in the five standard processes proposed by the National Council of Teachers of Mathematics (NCTM) (2000) (Puskur, 2005, Kur 2013). Students who have good problem solving ability are very likely able to solve problems related to mathematics and other fields of science as well as its application in the daily life of students. Therefore, in learning mathematics, problem solving ability is a very important ability developed; it is proven by making problem solving ability become the focus in learning mathematics in various countries. To solve non-routine mathematical problems or story problems, strategies or steps are formulated by Polya (1985) through four steps: (1) understand the problem; (2) plan the settlement; (3) carry out the problem as planned and (4) re-check all steps.

\section{Problem Based Learning}

Problem-based learning is a learning model that follows a change of view on the learning process from a teaching perspective to a teacher-centered learning or learning perspective to student-centered learning. These changes bring about a shift in view of understanding of mathematical knowledge, how students learn mathematics, and how the position of teachers in implementing the learning process.

According to Arends (in Trianto, 2010) problem-based learning is a learning approach where students work on authentic issues with the intent to structure their own knowledge, develop inquiry, and higher-order thinking, develop self-reliance and self-confidence. Thus, the problem-based learning model is a learning model that focuses more on the students who direct the students into independent learners and directly involved actively in group learning. There are five major stages that begin by introducing students to a problem that ends with the stage of student presentation and analysis. These five stages are presented in the following table (Trianto, 2010). 
Table 2.1. Syntax of Problem Based Learning Model

\begin{tabular}{|l|l|}
\hline \multicolumn{1}{|c|}{ Steps } & \multicolumn{1}{|c|}{ The Behaviour of Teacher } \\
\hline $\begin{array}{l}\text { Step 1. Oriented of } \\
\text { students' Problem }\end{array}$ & $\begin{array}{l}\text { The teachers explain learning objectives, explain required } \\
\text { logistics, propose phenomena or demonstrations or stories to } \\
\text { raise issues, motivate students to engage in problem-solving } \\
\text { chosen. }\end{array}$ \\
\hline $\begin{array}{l}\text { Steps 2. Organize } \\
\text { the students to } \\
\text { learn }\end{array}$ & $\begin{array}{l}\text { Teachers help students to define and organize learning tasks } \\
\text { related to the problem. }\end{array}$ \\
\hline $\begin{array}{l}\text { Steps 3. Guide the } \\
\text { individual and } \\
\text { group } \\
\text { investigation. }\end{array}$ & $\begin{array}{l}\text { The teachers encourage students to gather appropriate } \\
\text { information, conduct experiments, to gain explanations and } \\
\text { solve problems. }\end{array}$ \\
\hline $\begin{array}{l}\text { Steps 4. Develop } \\
\text { dan present the } \\
\text { Master's Work }\end{array}$ & $\begin{array}{l}\text { The teachers help students in planning and preparing } \\
\text { suitable works such as reports, videos, and models and } \\
\text { helping them to share tasks with their friends. }\end{array}$ \\
\hline $\begin{array}{l}\text { Steps 5. Analyze } \\
\text { and evaluate the } \\
\text { process of problem } \\
\text { solving }\end{array}$ & $\begin{array}{l}\text { Teachers help students to reflect on or evaluate their } \\
\text { investigations and process-porses they use. }\end{array}$ \\
\hline
\end{tabular}

\section{Population and Sample of the Research}

\section{THE RESEARCH METHOD}

The population of this study were 7th grade students of State and Private of Junior High School in Medan city taken by purposive random sampling, that is choosing eight SMP randomly with 4 State and 4 private Junior High School each from middle area of city and suburb.

\section{Research Approach}

This research was a developmental research. The steps of learning model development follow the procedure of developing Thiagarajan, Semmel \& Semmel (1974) learning model which refers to 4-D model (four D-Model). The 4-D model consists of 4 stages: define, design, development, and dissemination. Development of learning tools includes: Teacher Handbook, Student Book, Lesson Plan, Worksheet Students, and research instrument that is problem solving ability test, evidentiary ability. A summary of the modification of the 4-D model, which is a modification of Yuliani and Saragih (2015), is presented in Figure 4.1 below: 


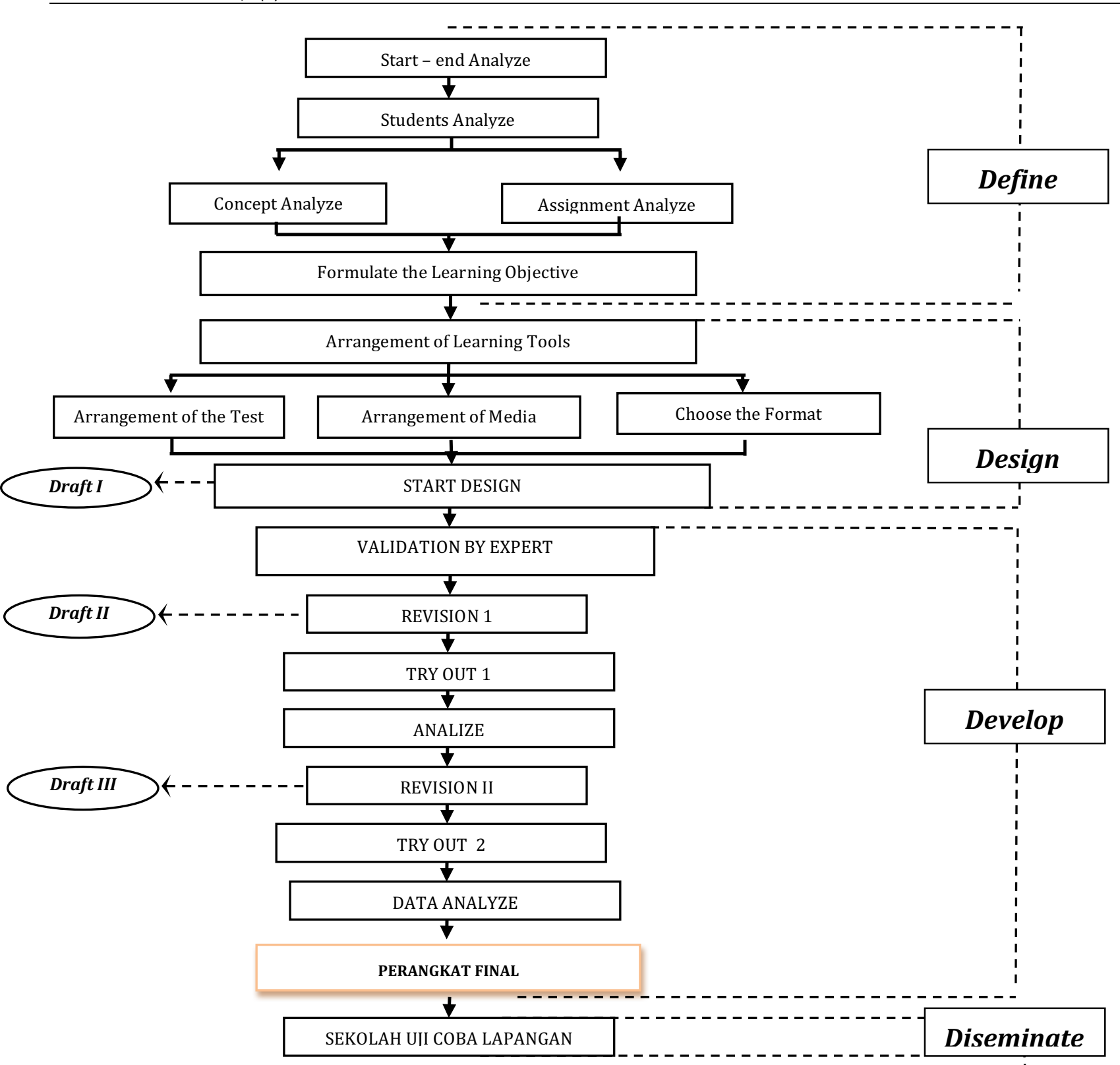

Figure 4.1 : Learning Tools Development Chart of Model 4-D

\section{Descriptions:}
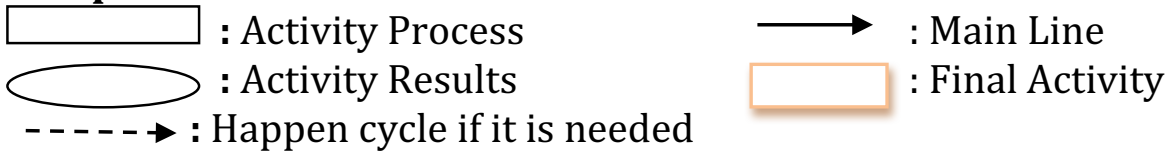

\section{Instruments and Techniques Data Analysis}

Instruments or data collection tools in this study were tests and observation sheets. The test was used to measure problem-solving abilities, while the observation sheet was used as an observation sheet on the implementation of learning tools developed in the classroom. Validity test used product moment correlation and reliability was used alpha formula, while for the effectiveness of learning device in terms of student learning completeness individually and classical, that was individually achieve score $\geq 65$, sedelas classically that if there were $85 \%$ of students who took the test has reached score $\geq 65$ All calculations used the help of SPSS program. 


\section{RESULTS AND DISCUSSION RESEARCH}

From the result of research indicate that both learning tool and instrument of research valid by validator and from result of field test shown same result that overall test have validity and reliability with high category, test reliability for mathematical problem solving ability equal to 0.873 for material number round while for equation and linear inequality matter obtained test reliability equal to 0.748 . The summary of validity and reliability is presented in the following table:

Table 1. Summary Reliability and Validity Item Problem Mathematical Problem Solving Matter on Matter of Integer

\begin{tabular}{|c|c|c|}
\hline Questions & $\boldsymbol{r}_{\boldsymbol{x y}}$ & Interpretasi \\
\hline \hline 1. & 0.841 & Valid and very Signicant \\
\hline 2. & 0.765 & Valid and very Signicant \\
\hline 3. & 0.843 & Valid and very Signicant \\
\hline 4. & 0.915 & Valid and very Signicant \\
\hline 5 & 0.795 & Valid and very Signicant \\
\hline \multicolumn{2}{|c|}{ Reliability: $\mathrm{r}_{11}=0,753=0.873$} \\
\hline
\end{tabular}

Table 2. Summary of Reliability and Validity Item Problem Mathematical Problem Solving Test on Material Equations and Linear Inequalities One Variable

\begin{tabular}{|c|c|c|}
\hline Questions & $\boldsymbol{r}_{\boldsymbol{x y}}$ & Interpretation \\
\hline \hline 1. & 0.639 & Valid and significant \\
\hline 2. & 0.799 & Valid and significant \\
\hline 3. & 0.774 & Valid and significant \\
\hline 4. & 0.804 & Valid and very significant \\
\hline \multicolumn{3}{|c|}{ Reliability: $\mathrm{r}_{11}=0,753=0.748$} \\
\hline
\end{tabular}

Besides, for the learning tool in the form of Student Activity Sheet there were revisions related to the change of picture, the sentence used, this was done to be more interesting and clarify from the Students Activity Sheet. The Students Activity Sheet revision can be seen in the following figure: 
Table 3. Revision of Students Activity Sheet after Try Out

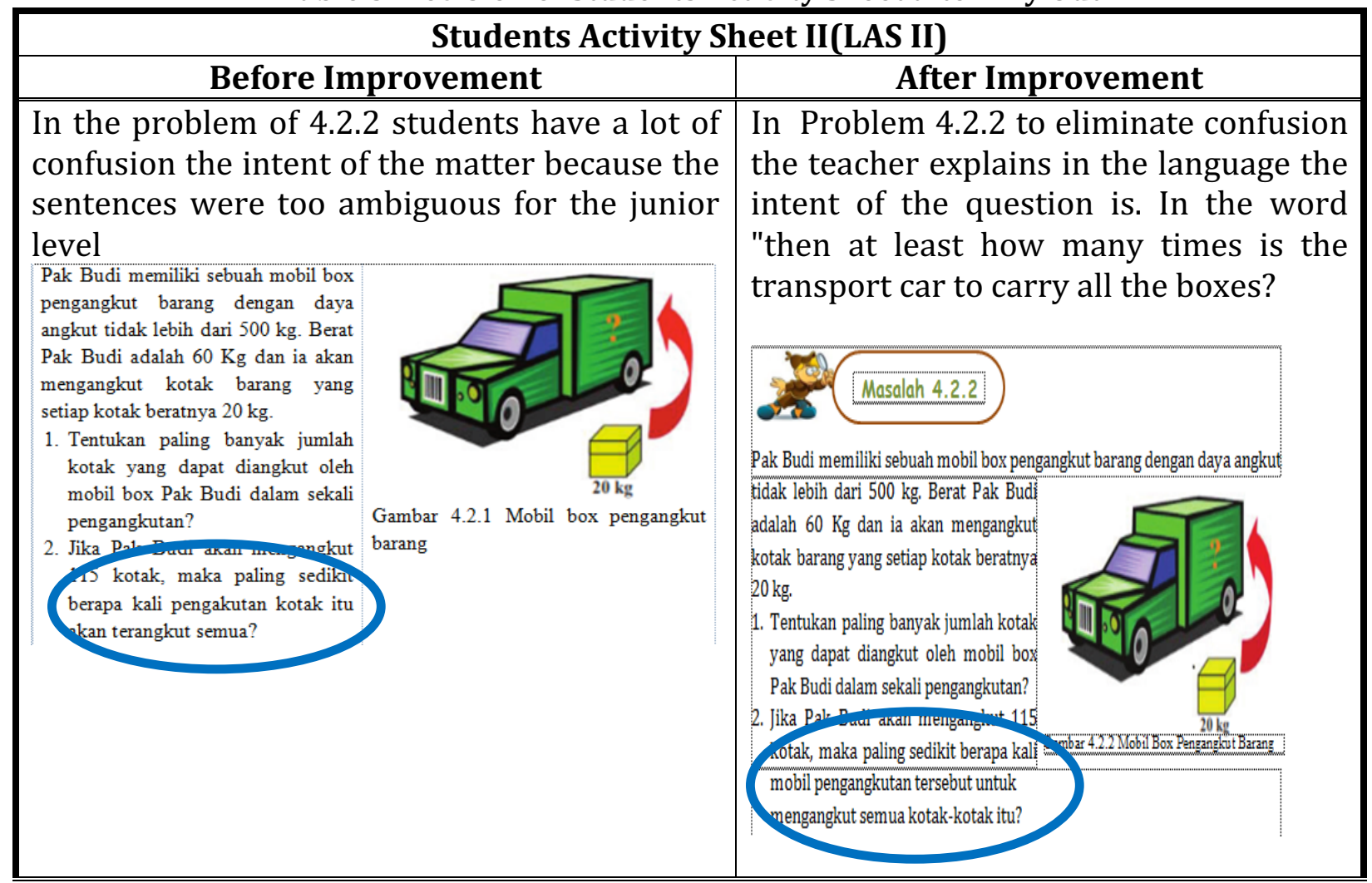

Table 4. Revision Students Answer Sheet (LAS) after Try Out Test

\begin{tabular}{|l|l|}
\hline \multicolumn{2}{|c|}{ Activity Sheet III (LAS III) } \\
\hline \multicolumn{1}{|c|}{ Before Improvement } \\
When working on LAS 3 on problem \\
4.3.1, there was an incorrect word.
\end{tabular}

From the results of the study showed that the test capabilities designed declared valid for use this shows that the test was appropriate to measure what should be measured in accordance with the material being taught. Likewise, a high level of test reliability indicates that the test will produce the same results (steady) when done repeatedly. This was in accordance with the opinion of Arikunto (2012) which states that a valid test and reliability indicated the accuracy and durability of the test, further said that the test has measured what should be measured, and will produce a steady result despite repeated. 
From result of development of learning tools in the form of Students Answer Sheet conducted limited trial on research sample that was student of class VII State Junior High School 36 Medan. The results showed that the students were very interested and motivated related to the problems related to the students' daily life (contextual) presented on the Students Answer Sheet. The presentation of contextual-based problems close to daily life makes learning more meaningful. According to Ausubel (Suparno, 1997), Piagget (Saragih, 2014, 2015) meaningful learning was a learning process in which new information was linked to the cognitive structure that a person is studying. Meaningful learning will occur when students try to connect new phenomena into the student's knowledge structure. Therefore, the understanding of the subject matter of the students and the real world context is very important to be considered for a teacher. This suggests that the problem-based learning model developed was valid for using.

The results of this study were in relating with Aufa and Saragih's research (2016) which shows that the problem-based learning model based on the Acehnese cultural context (PBM-BKBA) developed was valid for using. The same results were also obtained from the results of Sinaga (2007) study that developed a model of learning based on mathematics-based culture of valid batak used to improve the results and activities of high school students in North Tapanuli.

\section{CONCLUSION}

Based on the results of analysis and discussion in this study can be drawn some conclusions as follows:

1. Validity and reliability of test for high mathematical problem solving ability that is equal to 0.873 , for the matter of integer while for equation and linear inequality matter obtained test reliability equal to 0.748 .

2. The results of experimental learning tools in the form of Students Answer Sheet designed in relation to the daily life of students (contextual) with the problem-based learning model can make students interested and motivated.

\section{FOREWORD}

The author is aware of the many parties involved in assisting the completion of this journal. Therefore, the authors express their gratitude to all leaders and staff at UNIMED, DIKTI, and students who assist in the process of conducting research. Furthermore, the authors also say thank as much as possible to the principal, teachers and students State Junior High School (SMPN) 36 Medan.

\section{References}

Arends, R.I. (2008), Learning to Teach (Belajar Untuk Mengajar), Pustaka Pelajar, Yogyakarta.

Arikunto, S. (2012). Dasar-Dasar Evaluasi Pendidikan Edisi 2. Jakarta: Bumi Aksara.

Aufa, Saragih, Minarni, (2016), DevelopmentOfLearningDevices ThroughProblem BasedLearning Model Based OnTheContextOfAceh Cultural To Improve Mathematical CommunicationSkillsAndSocial Skills OfSmpn1 Muara BatuStudents,Journal of Education and Practice, IISTE, Vol 7. NO. 24; 2016, Published by International Institute for Science,Technology and Education Accelerating (IISTE) Global Knowledge Creation and Sharing.

Hia, Y. (2009), Pengaruh Pembelajaran Berbasis Masalah terhadap Hasil Belajar Siswa SMP, Laporan Penelitian IKIP Medan,

Kaur, B. (2004), Teaching Of Mathematics in Singapura Schools, Paper Presented at ICME-10 Copenhagen, Denmark.

Mandasari, L. 2013. Peningkatan Kemampuan Berpikir Kreatif dan Pemecahan Masalah Matematis Siswa SMA Melalui Model Problem Based Learning Menggunakan Software Autograph. Tesis. Medan: PPS UNIMED

National Council of Teacher of Mathematics. (2000). Principles and Standards for School Mathematics. Reston, VA: NCTM. 
Nufus. 2013. Peningkatan Kemampuan Pemecahan Masalah dan Komunikasi Matematis Melalui Penerapan Pembelajaran Berbasis Masalah Di Kelas VII SMPN. Tesis. Medan: PPS UNIMED

Polya, G. (1985), How to Solve It A New Aspect of Mathematics Method. Princeton University Press

Puskur. (2005). Kurikulum dan Hasil Belajar. Kompetensi Dasar Mata Pelejaran Matematika Sekolah Dasar dan Madrasah Ibtidaiyah. Balitbang, Depdiknas.

Ruseffendi, E.T. (1986). A Comparison of Participation in Mathematics of Male and Female Students in the Transition from Junior to Senior Hight School in West Java. Disertasi The Ohio State University. Ohio: Tidak Diterbitkan.

Saragih, S.(2013), Pengembangan Model Pembelajaran Berpusat Pada Siswa Untuk meningkatkan Kemampuan Matematika Tingkat Tinggi. Laporan Penelitian Hibah Pasca, Tahun Pertama, Unimed Medan, Medan.

Saragih,S. \& Habeahan, W.L, (2014), The improving of Problem Solving Ability and Students' Creativity Mathematical by Using Problem Based Learning in SMP Negeri 2 Siantar, Journal of Education and Practice, IISTE, VOL. 5, NO. 35, (123-132), Published by International Institute for Science,Technology and Education Accelerating (IISTE ) Global Knowledge Creation and Sharing.

Saragih, S., Napitupulu, E, (2015), Developing Student-Centered Learning Model to Improve High Order Mathematical Thinking Ability, International Education Studies; Vol. 8, No. 6, Mei 2015, Published by Canadian Center of Science and Education.

Sinaga, B. 2007. Pengembangan Model Pembelajaran Matematika Berdasarkan Masalah Berbasis Budaya Batak (PBMB3). Disertasi. Tidak dipublikasikan. Surabaya: Program Doktor Universitas Negeri Surabaya.

Yuliani, K. Saragih, S.(2015), The Development of Learning Devices Based Guided Discovery Model to Improve Understanding Concept and Critical Thinking Mathematically Ability of Students at Islamic Junior High School of Medan, Journal of Education and Practice, IISTE, Vol 6. NO. 24; 2015, Published by International Institute for Science,Technology and Education Accelerating (IISTE) Global Knowledge Creation and Sharing.

Trianto, (2010), Mendesain Model Pembelajaran Inovatif Progresif: Konsep Landasan dan Implementasinya pada Kurikulum Tingkat Satuan Pendidikan (KTSP), Jakarta: Pranada Media Grup.

Thiagarajan, S. Semmel, D.S. Semmel, M. 1974. Intructional Development for Training Teachers of Exceptional Children. A sourse Book. Blomington: Central for Innovation on Teaching The Handicapped. 